\title{
Unpacking the social media-driven innovation capability: How consumer conversations turn into organizational innovations
}

\author{
Joanne Patroni, Endpoint Consulting, Sydney, Australia, jpatroni@endpointconsulting.com.au \\ Frederik von Briel, University of Queensland, Brisbane, Australia, f.vonbriel@uq.edu.au \\ Jan Recker (corresponding author), University of Cologne, Cologne, Germany, \\ jan.recker@wiso.uni-koeln.de
}

\begin{abstract}
Given the scale and scope of consumer conversations on social media, it is both possible and challenging for organizations to identify valuable ideas from those conversations that could lead to successful innovations. We examine how a large retailer developed a new capability to leverage public social media conversations for innovation through a process of filtering, assessing, converting, and deploying. By inductively developing a process model of how the retailer managed to convert consumer conversations on social media into organizational innovation, our study sheds light on the microfoundations of this important capability.
\end{abstract}

Keywords: Digital innovation; open innovation; service innovation; social media; social media conversations, case study, IT capabilities; retail.

Acknowledgments: The research and data collection procedures were approved by the University Human Research Ethics Committee at Queensland University of Technology (approval no 1400000327). While working on this study, the first author was a doctoral student at Queensland University of Technology, partially supported by funding from Woolworths Group as part of a collaborative research agreement between Woolworths Group and Queensland University of Technology. Woolworths Group was not involved in research design, data analysis or reporting of findings. Dr Recker's contributions to this research were also partially funded through a grant by the Australian Research Council (DP160103407). 


\section{Introduction}

Innovation is the process of successfully implementing novel ideas that solve problems for an organization-even if these ideas might have already been implemented elsewhere (Glynn, 1996, p. 1094). Innovation is key for organizations to stay competitive and survive in today's fast changing business environment (Habersang, Küberling-Jost, Reihlen, \& Seckler, 2019; McKinley, Latham, \& Braun, 2014).

One way of achieving innovation is by opening up organizations to knowledge and ideas from the outside-a phenomenon called open innovation (Chesbrough, 2003). Traditionally, open innovation has been conducted either through collaborations with other organizations such as via alliances, contracted R\&D services, licensing agreements, R\&D Consortia, supplier collaborations, or university research grants (e.g., Chesbrough \& Brunswicker, 2014), or through collaborations with consumers via personal interviews, surveys, or focus groups (e.g., Roberts, Piller, \& Lüttgens, 2016). With the advent of digital technologies, open innovation also increasingly builds on dedicated systems, such as supply chain management systems (Rai, Pavlou, Im, \& Du, 2012), online innovation toolkits (Piller \& Walcher, 2006), online open innovation communities (Bayus, 2013; Dong \& Wu, 2015), or online crowdsourcing platforms (Dissanayake, Zhang, Yasar, \& Nerur, 2018; Schlagwein \& Bjørn-Andersen, 2014), which are purposefully developed and deployed to enable co-creation with external stakeholders.

The rise of social media platforms, however, provides organizations with an alternative pathway to tap into vast amounts of external knowledge and ideas (Majchrzak \& Malhotra, 2013)-without the need for collaboration. Consumers frequently use social media platforms such as discussion forums, online product review platforms, social networks, and blogs to verbalize their opinions about products and services (Olsen \& Christensen, 2015; Sorescu, Frambach, Singh, Rangaswamy, \& Bridges, 2011). Both scale and scope of the conversations taking place on such platforms are constantly growing and in flux. For example, in 2016, at the time of our study, Facebook alone had 1.23 billion daily active users (Facebook, 2016) who created 510,000 comments every 60 seconds (Noyes, 2017). These conversations have substantial implications for organizations. For example, they can 
influence organizations' product sales (Dewan \& Ramaprasad, 2014; Oh, Roumani, Nwankpa, \& Hu, 2017) and even stock market valuations (Deng, Huang, Sinha, \& Zhao, 2018; Luo \& Zhang, 2013). An increasing number of organizations thus try to tap into consumer conversations on social media for innovation purposes (Roberts et al., 2016; Tan \& Zhan, 2017). Yet, neither have these social media platforms been developed or deployed for, nor is the majority of conversations taking place on them created for, innovation purposes (Rayna \& Striukova, 2015), which makes them difficult to leverage (Abbasi, Zhou, Deng, \& Zhang, 2018).

This tension between the enormous mass and critical importance of social media conversations on the one hand, and the difficulty to understand them on the other hand, imposes challenges for organizations: they need to be able to not only acquire and respond to (Gunarathne, Rui, \& Seidmann, 2018), but also filter and assess the vast amount of conversations on social media to identify knowledge and ideas with innovation potential that may be hidden in it.

Yet, the literature on these topics (open innovation, digital platforms for innovation, and social media use) has so far built on assumptions that, taken together, neglect this possibility: the literature on open innovation by and large presumes that consumers are actively involved in innovation, as the term co-creation implies (Chesbrough \& Brunswicker, 2014; Randhawa, Wilden, \& Hohberger, 2016). The literature on digitalization of innovation management is focusing on platforms, toolkits and communities that have been designed for innovation (Dong \& Wu, 2015; Schlagwein \& Bjørn-Andersen, 2014), neglecting those that are not but could be appropriated as such. The literature on the use of public social media by organizations by and large focuses on how organizations could communicate via or respond to conversations they listen to (Gunarathne et al., 2018; Schlagwein \& Hu, 2017) but not how organizations can leverage these conversations. In fact it has already been acknowledged that little is known about how social media conversations of consumers that might not have been created for innovation purposes may result in organizational innovation (Roberts et al., 2016; Stanko, Fisher, \& Bogers, 2017). We report on a revelatory case that breaks with these three assumptions. Our analysis of this case provides a first empirical answer to the question: 
How can organizations leverage consumer conversations that take place on social media for their innovation purposes-even if consumers did not necessarily start or engage in these conversations with the purpose of helping organizations?

To answer this research question, we conducted an inductive case study (Eisenhardt, 1989; Locke, 2007; Myers, 2009) with one of the world's largest retailers. The retailer established dedicated social media functions in its major subsidiaries with the purpose of leveraging consumer conversations on social media to innovate its services. This setting makes the retailer a particularly revelatory case because consumer conversations on social media are critically important for organizations in the retail sector (Gallaugher \& Ransbotham, 2010; Phan, Thomas, \& Heine, 2011). Most relevant to our paper is that consumers frequently share and discuss both negative and positive retail experiences publicly on social media, which has led to retailers developing the capability to listen and respond to this feedback (Constantinides, Romero, \& Boria, 2008; Stephens, 2013). What has been overlooked so far is the development of an organizational capability to leverage these conversations for innovation, which is what our case organization has managed to achieve and what we focus on in this paper.

Through our work, we make three primary contributions. First, by identifying social media-driven innovation as an important capability and shedding light on the actions and decisions of individuals that underlie it, we contribute to the literature on IT capabilities (a specific set of organizational capabilities, see Kim, Shin, Kim, \& Lee, 2011; Rai \& Tang, 2010; Saldanha, Mithas, \& Krishnan, 2017) and to the literature on microfoundations of organizational capabilities (the actions and interactions of individuals that give rise to them, see Bogers, Foss, \& Lyngsie, 2017; Felin, Foss, Heimeriks, \& Madsen, 2012; Felin, Foss, \& Ployhart, 2015). Second, by providing a detailed account of how one of world's largest retailers innovates based on consumer conversations on social media that have not necessarily been created for innovation purposes, we contribute to the understanding of how digital technologies can trigger, enable, and shape open innovation (Nambisan, Lyytinen, Majchrzak, \& Song, 2017; Randhawa et al., 2016). Third, by identifying how consumer conversations on social media trigger, traverse, and influence the trajectories of organizational innovation, we contribute to the understanding of the end-to-end open innovation process in service contexts (Barrett, Davidson, Prabhu, \& Vargo, 2015; West \& Bogers, 2017). 
We proceed as follows: we review relevant literature about innovation in the service sector and about IT capabilities and social media as an innovation enabler to establish our focal context and technology artifact. Next, we elaborate our inductive case study method to subsequently report our findings and introduce the social media-driven innovation process model. We then use a vignette to illustrate how our process model can explain a real-world innovation project at the case organization. Lastly, we discuss the implications of our findings for research and practice, and end with a conclusion.

\section{Background}

\subsection{Service Innovation as the Setting of our Study}

The service sector accounts for more than $60 \%$ of the global gross domestic product (GDP) (CIA, 2017). However, despite the sector's global importance, service innovation has received limited attention from researchers so far (Barrett et al., 2015; West, Salter, Vanhaverbeke, \& Chesbrough, 2014). We briefly mention three studies that did focus on this area: Mention (2011) shows that external knowledge sources such as customers and suppliers positively influence the market novelty of service innovations in service sector organizations; Mina, Bascavusoglu-Moreau, and Hughes (2014) show that service sector organizations engage more in informal open innovation practices such as lead user interaction than their manufacturing counterparts do; and Love, Roper, and Bryson (2011) show that service sector organizations benefit particularly from engaging with customers in the early exploratory stages of the innovation process.

Service innovation differs from product innovation mainly because of the specific characteristics of services (Hipp \& Grupp, 2005; Nijssen, Hillebrand, Vermeulen, \& Kemp, 2006; Vargo \& Lusch, 2008): services are intangible, perishable, and produced for each individual consumer in real time at the point of use. In other words, services fleetingly emerge through interactions between organizations and consumers when the earlier deliver and the latter use a service, which means that services can be adapted in real time to consumer needs. Hence, in service innovation "it is not the service itself that is produced but the pre-requisites for the service" (Edvardsson, Haglund, \& Mattsson, 1995, p. 1476). This stands in contrast to traditional products such as bicycles, cars, furniture, medical devices, and phones, which are tangible, endure over time, and are produced before consumers use them. 
For example, a retailer delivers a personalized service in real time each time somebody obtains purchasing advice from a store employee and/or purchases a product from it. The system put in place to enable the delivery of this service including, for example, the physical store, stocked shelves, trained store employees, point-of-sales systems, etc., can be influenced by the retailer to innovate the service, but the service itself is always produced in real-time for each individual customer. By contrast, the product that is sold by the retailer has been developed, tested, and manufactured by a producer before it was sold to the retailer and in turn the consumer. As a result of this difference, the integration of and fit between innovations and existing organizational systems is more important in service innovation contexts than in product innovation contexts (Nijssen et al., 2006).

However, similar to product innovation, service innovations can be improvements, incremental, or radical (Gallouj \& Weinstein, 1997). With improvement innovations, certain characteristics of a service are improved such as when an online retailer shortens its delivery times, but the service itself remains largely unchanged; with incremental innovations, individual service elements are added to and/or substituted from a service such as when an online retailer adds a guaranteed delivery time; with radical innovations, a completely new service is created such as when a previously purely online retailer like Amazon or Warby Parker establishes physical stores where consumers can then experience products and immediately fulfill their needs. Most service innovations are based on imitation rather than invention and thus, are rather incremental and new to the firm but not necessarily to the market (Hipp \& Grupp, 2005).

\subsection{Social Media as a Digital Technology Enabling New IT Capabilities}

IT capabilities broadly refer to organizations' abilities to use IT to improve organizational outcomes such as new product development efficiency and effectiveness, customer satisfaction, or financial performance (Kim et al., 2011). Researchers have identified various dimensions of IT capabilities such as the availability of IT infrastructure, human IT resources, and IT business experience (Bharadwaj, 2000; Bhatt \& Grover, 2005; Zhang, Sarker, \& Sarker, 2008). Researchers have also identified different types of IT capabilities such as information management capabilities (Mithas, Ramasubbu, \& Sambamurthy, 2011), interfirm information processing capabilities (Wang, Tai, \& Grover, 2013), IT-enabled 
knowledge capabilities (Joshi, Chi, Datta, \& Han, 2010), and cross-channel capabilities (Luo, Fang, \& Zhang, 2016). Hence, rather than being an unequivocal construct, IT capabilities constitute a range of different capabilities that can all influence organizational outcomes. However, while conceptualizations of IT capabilities vary, researchers generally agree that organizations can develop IT capabilities through investments in their abilities to use specific digital technologies that bear the potential to improve organizational outcomes (Kim et al., 2011; Rai et al., 2012).

Social media refers to internet-based digital technologies such as blogs, social networking sites, and wikis that allow their users to create and exchange content (Kaplan \& Haenlein, 2010). It carries the proclaimed potential to spawn new capabilities, largely because it offers a range of generative affordances (Treem \& Leonardi, 2012) that organizations could potentially leverage for service innovation (Leonardi, 2014; Lusch \& Nambisan, 2015). However, research that has examined social media based open innovation has so far built on the assumption that consumers intentionally generate content on social media to be used for innovation by organizations (Candi, Roberts, Marion, \& Barczak, 2018; Schlagwein \& Hu, 2017). Prior research has usually either focused on the perceptions and motivations of consumers who contribute to organizational innovation efforts (Füller, Hutter, \& Faullant, 2011; Füller, Mühlbacher, Matzler, \& Jawecki, 2009) or the organizational benefits that flow from these focused collaborations (Candi et al., 2018; Piller \& Walcher, 2006; Schlagwein \& Bjørn-Andersen, 2014).

Observations of practice (Gallaugher \& Ransbotham, 2010; Phan et al., 2011) and recent open innovation research (Roberts et al., 2016; Tan \& Zhan, 2017), however, indicate that organizations can also innovate based on social media content that has not been created for this purpose. For example, Roberts et al. (2016) show that consumer information acquired from social media can positively influence new product development if organizations have formalized development processes and Tan and Zhan (2017) show that analysis of social media content can improve the speed and decrease costs of new product development.

Research outside of the open innovation context generally attests social media a transformative characteristic (Kane, Alavi, Labianca, \& Borgatti, 2014) and shows that it can make formerly invisible interactions, relationships, and knowledge visible 
for third parties (Leonardi, 2014). This is particularly the case in the retail sector where consumers frequently use social media to publicly share their opinions and discuss various topics, products, and services with large numbers of potentially unknown people (Matook, Brown, \& Rolf, 2015). Retailers are strongly affected by these conversations because they influence consumers' purchasing decisions and retailers' profitability (Bolton, Katok, \& Ockenfels, 2004; Duan, Gu, \& Whinston, 2008). Hence, the accessibility of publicly available consumer conversations creates opportunities for organizations such as retailers to leverage social media for their innovation efforts. Yet, it remains largely unclear how organizations can develop capabilities to benefit from the wealth of consumer conversations on social media (Kietzmann, Hermkens, McCarthy, \& Silvestre, 2011). Moreover, the humongous and constantly growing amount of conversations accessible on social media impose new challenges for organizations to source, filter, extract, and use potentially hidden knowledge and ideas for innovation purposes (Whelan, Teigland, Donnellan, \& Golden, 2010).

\section{Method}

With limited empirical evidence on our focal phenomenon in context in the extant literature, we adopted an inductive, qualitative research design (Eisenhardt, 1989; Myers, 2013) to generate theory from case study (Eisenhardt, 1989).

\subsection{Case study setting}

Our case study is situated in the retail sector. The retail sector accounts for 31 per cent of the global Gross Domestic Product (GDP) and is an important element of both the global economy and the service sector. In the retail sector, organizationsreferred to as retailers-create value by providing services to consumers. Products and their accessibility for consumer are an important element of service delivery in the retail sector. In turn, consumers have started to leverage social media not only to identify the best products and services but also to complain about products and services that are below expectations (Constantinides et al., 2008; Sorescu et al., 2011). These conversation often take place in real-time during service delivery and can reach a large audience, thereby creating a dynamic high-velocity environment that retailers have to deal with (Gunarathne et al., 2018). In response, retailers are increasingly attempting to engage with consumers on social media to learn from them and ultimately to innovate their services and improve their market position 
(Cameron, 2014; Mason, 2015). Hence, the retail sector provides a particularly suitable context to study the role of social media in open service innovation.

Our case study focuses on one of the world's 25 largest retailers (Deloitte, 2017) that operates more than 3,000 stores in Australia. While the retailer sells a small range of private-label products under its own brand name, all of its products are sourced externally and the vast majority is sold under the labels of external brands. The retailer did not have dedicated R\&D functions for innovation. This is common for service organizations, at least the ones in low-medium-tech sectors, as they usually do not pursue innovation systematically (Hipp \& Grupp, 2005). Instead, innovation was actioned independently by each of the retailers' subsidiaries. The subsidiaries also often worked directly with suppliers to help them adapt their products to market demands.

This situation changed in 2013 when the retailer implemented dedicated positions, processes, and tools for leveraging consumer conversations on social media for innovation purposes in each of its three major subsidiaries: grocery, liquor, and loyalty. Grocery operated the retailer's main supermarket chain with about 1,000 physical stores; liquor operated the retailer's liquor store chains with about 1,500 physical stores and different brands for different customer segments; and loyalty operated the retailer's rewards program which offered members-only deals across chains and had about 11 million users. This organizational move towards establishing the capability to innovate based on consumer conversations on social media provides the setting for our case study. The retailer's three subsidiaries serve us as mini-cases that strengthen our empirical grounding and enable cross-case comparison (Eisenhardt, 1989). In each subsidiary, the retailer created dedicated social media manager positions that had the responsibility to listen to, action, and manage consumer conversations on social media that was publicly accessible without the need to request permission. Together with these positions, the retailer implemented digital tools that enabled the subsidiaries to listen, filter, and respond to consumer conversations on social media. Of the social media conversations that consumers generated in relation to the three subsidiaries, 80 percent was on Facebook, which was also the only social media channel where the retailer maintained official presences. The remaining 20 percent of social media conversations were distributed across Google Plus, Instagram, Twitter, and 
YouTube. Hence, Facebook provided the most important social media-based consumer touchpoint for the retailer.

\subsection{Case study design}

We followed extant recommendations for inductive case study research (Eisenhardt, 1989; Gioia, Corley, \& Hamilton, 2013; Urquhart, 2013) to design our case study. First, for theoretical sampling we selected the three subsidiaries, grocery, liquor, and loyalty, because these three had at the time of our study successfully perused consumer conversations on social media for innovation, whereas others (e.g., hotels, hardware) had not. Second, we collected data from multiple sources to be able to triangulate and corroborate our findings as well as to obtain a holistic understanding of how consumer conversations on social media result in innovation for the retailer. Third, we adjusted our data collection over time to obtain an increasingly focused understanding of the focal phenomenon and to sharpen the emergent themes. Fourth, we tabulated evidence of the mini-cases and different data sources to sharpen concept definitions, establish plausibility, and enable corroboration.

Specifically, we began by gathering primary data via semi-structured interviews with 44 consumers between June and July 2016. Consumer interviews had an average duration of 45 minutes. Although they were not limited to, the vast majority of participants were customers of at least one of the focal retailer's subsidiaries. The goal of the interviews was to obtain a broad understanding of consumers' motivations for and expectations of starting and engaging in product and/or service-related social media conversations. As such, the interviews helped us to gain a contextual understanding of conversations from the consumer perspective and subsequently served as a foundation to corroborate other data sources and our emerging findings. We recruited consumers via public social media advertisements. Participating consumers were between 18 and 75 years old, with 16 participants less than 36 years of age and 28 participants over 36 years of age. 25 participants were female and 19 were male. All participating consumers were regular social media users and most of them (36) regular Facebook users, with 17 participants using social media at least once a day, 19 using it up to four hours a day, and 8 using it more than four hours a day.

Next, we gathered primary data via semi-structured interviews from the retailer's three social media managers between July and August 2016. Each social media 
manager was employed by the marketing division of one of the retailer's subsidiaries (i.e., grocery, liquor, and loyalty) and was part of this division's dedicated social media team. In these teams, each of the social media managers was in charge of managing consumer conversations on social media for their subsidiary. That is, each social media manager had the responsibility to identify social media conversations with innovation potential for their subsidiary and to action it in conjunction with related department managers. Having very similar roles in the same overarching organization, all three social media managers also shared knowledge and discussed with each other across subsidiaries. Interviews lasted up to an hour and focused on the formal processes and informal routines performed by social media managers as they collect and analyze consumer conversations on social media and decide on actions where appropriate. Each of the three social media managers was less than 30 years old, had worked between two and three years in their positions at the retailer, plus at least five years for other organizations in social media-related roles prior to joining the retailer (e.g., online marketing manager, online community manager). Hence, each of the social media managers had at least seven years of total work experience in social media related roles.

In September 2016, we then gathered and analyzed secondary data in the form of consumer conversations from each of the three subsidiaries' Facebook pages. Specifically, we gathered between 130 and 245 consumer conversations for each of three subsidiaries' Facebook pages that were popular, i.e., that had received considerable attention from consumers, defined as having received eight or more comments each from different consumers. Each conversation in our sample had between 8 and 30 comments. We did not take the length of individual comments into account: some comments were only one line short, others contained more than one feedback item. However, conversations with eight or more comments provided rich enough dialogs to understand even short posts and to identify predominant conversation themes. This analysis allowed us to better understand the consumer conversations that provided impetus for social media managers' actions and the innovation projects that resulted from them. Specifically, we collected consumer conversations that had been created between December 5, 2015, and September 29, 2016, and cross-checked them with the social media manager interviews, consumer interviews and announcements, advertisements, and general information on the retailer's subsidiary web sites. 
Finally, in February 2017 we discussed and verified our findings over a 30-minute interview with a senior executive of the retailer. Table 1 provides an overview of our data sources.

Table 1. Overview of data sources

\begin{tabular}{|c|c|c|}
\hline Data Type & Data Source & Use in Analysis \\
\hline \multirow[t]{4}{*}{ Primary data } & $\begin{array}{l}\text { Preliminary consumer interviews } \\
(n=44)\end{array}$ & $\begin{array}{l}\text { Familiarize with consumer conversations related to } \\
\text { retail innovation. Compare with emerging findings. }\end{array}$ \\
\hline & $\begin{array}{l}\text { Interviews with social media } \\
\text { managers }(n=3)\end{array}$ & $\begin{array}{l}\text { Identify formal processes and informal routines } \\
\text { through which consumer conversations on social } \\
\text { media gets translated into innovation. }\end{array}$ \\
\hline & $\begin{array}{l}\text { Informal conversations with } \\
\text { social media managers }(n=2)\end{array}$ & $\begin{array}{l}\text { Improve understanding of the social media-driven } \\
\text { innovation process. Triangulate and integrate with } \\
\text { evidence from secondary data. }\end{array}$ \\
\hline & $\begin{array}{l}\text { Interview with senior executive } \\
\text { with subject matter expertise } \\
(n=1)\end{array}$ & $\begin{array}{l}\text { Verify understanding of the social media-driven } \\
\text { innovation process. Triangulate and integrate with } \\
\text { evidence from interviews with social media } \\
\text { managers and conversations from social media. }\end{array}$ \\
\hline \multirow[t]{2}{*}{$\begin{array}{l}\text { Secondary } \\
\text { data }\end{array}$} & $\begin{array}{l}\text { Popular (i.e., }>=8 \text { responses) } \\
\text { consumer conversations on } \\
\text { social media on the retailer's } \\
\text { grocery ( } n=135) \text {, liquor }(n=130) \text {, } \\
\text { and loyalty }(n=244) \text { Facebook } \\
\text { homepages ( } 9 \text { months period) }\end{array}$ & $\begin{array}{l}\text { Identify and understand consumer-conversations } \\
\text { with innovation potential and respective actions of } \\
\text { the retailer. Triangulate and integrate with evidence } \\
\text { from interviews with the social media managers } \\
\text { and product and service information available on } \\
\text { the retailers' subsidiary web sites. }\end{array}$ \\
\hline & Retailer's subsidiary web sites & $\begin{array}{l}\text { Identify and understand innovations that originated } \\
\text { from consumer conversations on social media via } \\
\text { official announcements, advertisements, and } \\
\text { general information. Triangulate and integrate with } \\
\text { evidence from interviews with social media } \\
\text { managers and conversations from social media. }\end{array}$ \\
\hline
\end{tabular}

\subsection{Data analysis}

We followed typical procedures for inductive data analysis (Charmaz, 2006; Gioia et al., 2013; Miles \& Huberman, 1994). We crafted vignettes as thick descriptions (Denzin, 2001; Miles, 1990), and let the codes emerge from interview data and our other collected materials (Corbin \& Strauss, 2015). Through the typical process of open, axial, and selective coding, we created a more manageable number of higherlevel categories, and iterated between data and theory to bring clarification to emergent themes and concepts (Urquhart, 2013).

During open coding, we analyzed interviews and consumer conversations on social media line-by-line and coded individual text elements to create first-order codes. We 
used terms and phrases used by the interview participants or consumers (i.e., in vivo codes) as codes whenever possible. Since each text element can hold more than one piece of information, we often assigned multiple codes to one text element. We revisited existing codes throughout the open coding process to determine whether codes with similar meanings could be merged and refined.

During axial coding, we created second-order codes by grouping codes into more abstract categories and coded the primary data for connections between categories and their meaning. This resulted, for example, in the identification of the decisions taken by the retailer and conversation types created by consumers. Based on our emerging findings, we also started to use literature on microfoundations-the actions and interactions of individuals that give rise to organizational capabilities (Felin et al., 2012; Teece, 2017)_as a sensitizing device (Urquhart, 2013) during later stages of axial coding to hone in on tasks, roles, and decisions of the social media-driven innovation process.

During selective coding, we analyzed the relationships between second-order codes and connections to identify interrelated core categories. We separated two aspects: From the analysis of the social media manager interviews, this step resulted in our sequential process model, with each core category representing one process step. I From the analysis of the consumer conversations on social media, this step resulted in the identification of three overarching types of conversations with innovation potential and the verification of individual process steps.

All of us discussed and refined the coding (Klein \& Myers, 1999) until we reached a stable and shared interpretation of the data. Our resulting coding tree is shown in Figure 1. Finally, we reviewed our process model with a senior executive with subject matter expertise at the retailer to confirm why some consumer conversations lead to innovations at the retailer while others did not. 
- Poor employee treatment

- Poor quality customer service

- Product issues

- Sensitive or political items

- Loyalty program questions

- Product questions

- Price questions

- Online system questions

- Other miscellaneous questions

- New product ranges

- Environmentally friendly practices

- Advance notice of produce changes

- Loyalty program ideas

- Pay on delivery for online orders

- New store locations

- Offer price match or special prices for products

- Improve store opening hours

- Share grocery bags between customers

- Ungrade card scanners in store

- Increased discussions of the topic

- Increased likes of the topic

- Increased shares of the topic

- Content important to retailer

- Content aligns with retailers convictions

- Content aligns with retailers preferences

- Content aligns with retailers objectives or priorities

- Listen broadly to topics

- Provide closing response to topic

- Track idea status in innovation logs

- Report information to business owners

- Business owners decide to pause idea

- Continue listening to conversations

- Track idea status in innovation logs

- Report information to business owners

- Business owners decide to action idea

- Track idea status in innovation logs

- Report information to business owners

- Business owners decide to reject idea

- Engage in further conversation with consumer for ideation

- Provide a web site link to consumer for further information about retailers services or business objectives

- Provide a URL link to consumer for private conversation

- Inform consumers about the progress of idea implementations

- Promote upcoming idea launches

- Listen actively to consumer to consumer conversation

- Listen actively to consumer to retailer conversations

- Create innovation logs and problem reports

- Report social media sentiment to busines owners

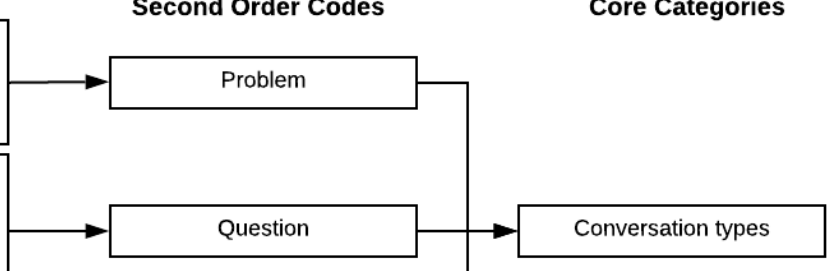

- Publicly acknowledge topic

- Provide public update about the internal status

- Update the public on resulting actions taken

Figure 1. Coding tree

\section{Analysis and Findings}

We report on our findings by first identifying three types of consumer conversations on social media that provide innovation impetus for the retailer, then describing the process of how the retailer leverages these conversations for innovation, and lastly describing a specific episode of how consumer conversations on social media traversed into an innovation at the retailer. 


\subsection{Consumer conversations on social media that stimulated innovation}

According to the social media managers, approximately $5-10 \%$ of all consumer conversations on the subsidiaries' Facebook pages trigger innovation at the retailer. This figure is remarkable by comparison: for example, only $4 \%$ of suggestions submitted via Dell's IdeaStorm led to innovations (Bayus, 2013) and less than $1 \%$ of all suggestions submitted via MyStarbucksldea.com led to innovations at Starbucks (Dong \& Wu, 2015) — both dedicated platforms that have been exclusively developed and deployed for open innovation purposes. The ratio of suggestions to innovations is even on organization-internal innovation platforms usually well below 10\% (Recker, Malsbender, \& Kohlborn, 2016).

The majority of conversations with innovation potential for the retailer arose from problems and queries (90\%), viz., conversations that consumers did not engage in to support innovation but rather to complain about, and potentially solve, issues they experienced. Only a minority of conversations with innovation potential can be attributed as being explicit suggestions that consumers purposefully posted to support innovation (10\%). As one social media manager stated, "I would say the majority of [innovation] comes from customer problems. There aren't necessarily many ideas that we would get directly from a customer that would pitch to us a suggestion about doing something differently. I think it generally - the root cause is from the problem itself. So, I would say that everything that, you know, it's addressing the direct problem a customer has with an innovative solution." Hence, social media conversations that the retailer used for its innovation activities differed substantially from purposefully generated innovation suggestions prevalent in studies of traditional social media-based innovation initiatives, such as Dell's Idea Storm (Bayus, 2013) or/and Lego's Mindstorm (Schlagwein \& Bjørn-Andersen, 2014).

Our subsequent analysis of the retailers' Grocery, Liquor, and Loyalty Facebook pages revealed that the majority of popular consumer posts (i.e., those that received more than eight comments) relate to problems ( $76 \%$ avg.) in form of product issues and poor consumer service, followed by queries about products and services (16\% avg.), and lastly suggestions for improvements ( $8 \%$ avg.). Hence, the distribution of conversation types on social media closely resembled the general distribution of social media conversations that the social media managers considered as having innovation potential. Further analysis of consumer conversations on the retailers' Facebook pages (see Table 2) showed that the majority of conversations relate to 
product issues (265) and poor consumer service (116), followed by questions about products and services (82) and product suggestions (40).

\begin{tabular}{lcccc}
\hline Facebook consumer conversations & Grocery & Liquor & Loyalty & Total \\
\hline Problem & 92 & 85 & 211 & 388 \\
- Employee treatment & 3 & 0 & 0 & 3 \\
- Poor consumer service & 40 & 72 & 4 & 116 \\
- Product issues & 45 & 13 & 207 & 265 \\
- Sensitive or political items & 4 & 0 & 0 & 4 \\
Questions & 31 & 35 & 16 & 82 \\
Suggestion & 12 & 10 & 18 & 40 \\
- Product idea & 8 & 8 & 14 & 30 \\
- Service idea & 4 & 2 & 4 & 10 \\
\hline
\end{tabular}

Table 2. Breakdown of consumer conversations on the retailer's Facebook pages

\subsection{The social media-driven innovation process}

Analysis and interpretation of our case data led us to formulate a model of the social media-driven innovation process at the retailer that shows the microfoundations of this new capability. This process has four sequential stages-Listening, Assessing, Converting, and Deploying-through which consumer-generated comments and conversations on social media result in innovation at the retailer, and one stage that runs in parallel and can be executed at any time-Responding. Figure 2 shows this process of conversation-to-innovation translation and Table 3 explains the decisions that are taken throughout the process and the implications each of them has. We discuss the five process stages and the decisions that are taken in each in more detail in the following. 


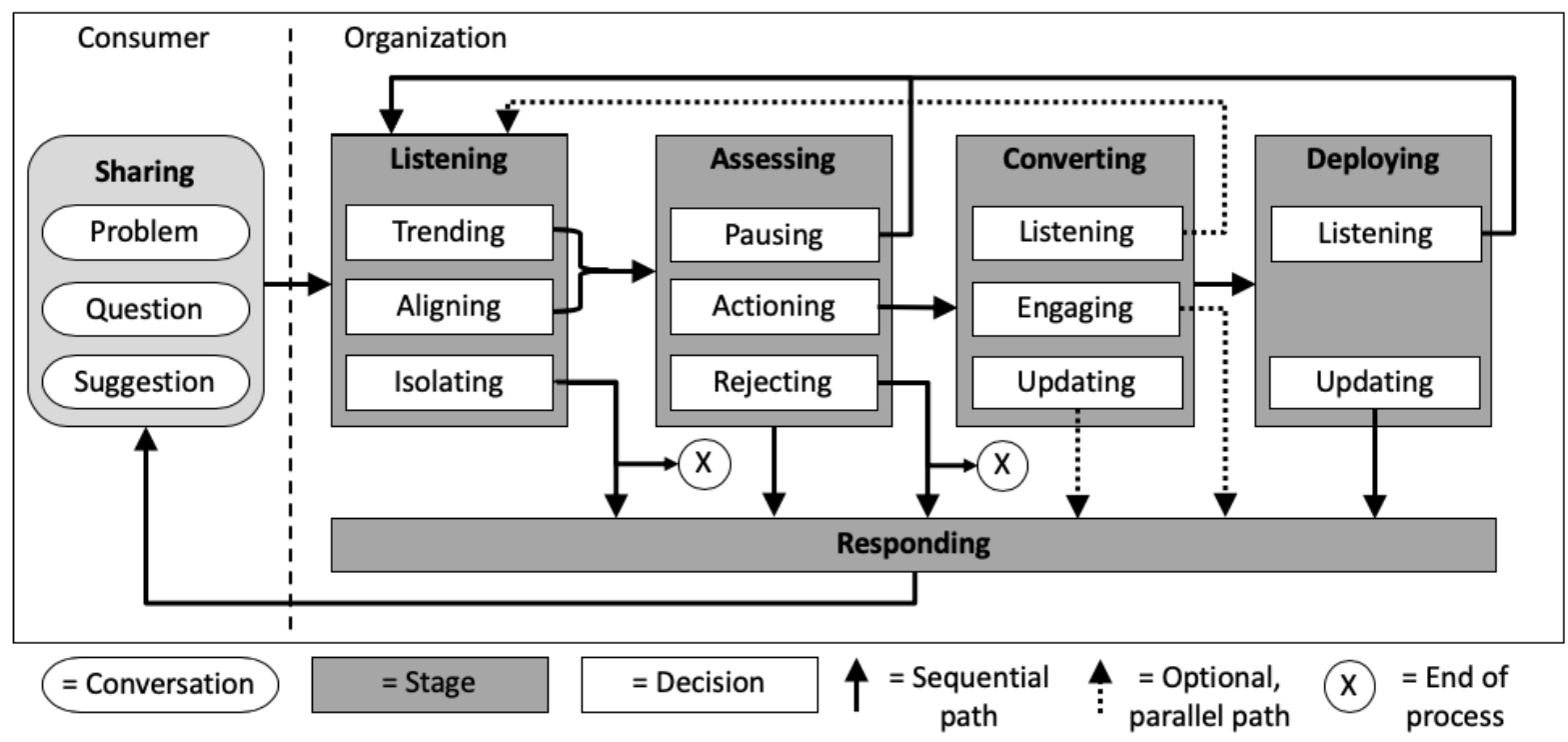

Figure 2. Model of the social media-driven innovation process

\begin{tabular}{|c|c|c|c|}
\hline $\begin{array}{l}\text { Process } \\
\text { stages }\end{array}$ & $\begin{array}{l}\text { Decisions } \\
\text { taken }\end{array}$ & Roles and Explanations & Implications \\
\hline \multirow[t]{4}{*}{ Listening } & & $\begin{array}{l}\text { Social media managers analyze current } \\
\text { consumer conversations to identify and } \\
\text { select conversations that... }\end{array}$ & \\
\hline & Trending & ... are popular among consumers & Moves to Assessing stage \\
\hline & Aligning & ... align with the organizational strategy & Moves to Assessing stage \\
\hline & Isolating & ... concern only few consumers & $\begin{array}{l}\text { Triggers Responding stage, } \\
\text { no further actions }\end{array}$ \\
\hline Responding & & $\begin{array}{l}\text { Social media managers reply to consumer } \\
\text { conversations on social media }\end{array}$ & Triggers Listening stage \\
\hline \multirow[t]{4}{*}{ Assessing } & & $\begin{array}{l}\text { Business stakeholders decide whether } \\
\text { conversations that have passed the } \\
\text { Filtering stage ... }\end{array}$ & Triggers Responding stage \\
\hline & Actioning & $\begin{array}{l}\text {... provide sufficient potential for innovation } \\
\text { to be implemented }\end{array}$ & Moves to Converting stage \\
\hline & Pausing & $\begin{array}{l}\text {... need to be observed for a longer period of } \\
\text { time to better understand their innovation } \\
\text { potential }\end{array}$ & $\begin{array}{l}\text { Moves back to Listening } \\
\text { stage }\end{array}$ \\
\hline & Rejecting & ... provide insufficient innovation potential & $\begin{array}{l}\text { Triggers Responding stage, } \\
\text { no further actions }\end{array}$ \\
\hline \multirow[t]{4}{*}{ Converting } & & $\begin{array}{l}\text { Business stakeholders implement ideas and } \\
\text { decide whether they want to... }\end{array}$ & \\
\hline & Listening & $\begin{array}{l}\text {... gather additional information from } \\
\text { consumers via passive listening }\end{array}$ & $\begin{array}{l}\text { Triggers Listening stage in } \\
\text { parallel }\end{array}$ \\
\hline & Engaging & $\begin{array}{l}\text {... gather additional information from } \\
\text { consumers via dialog }\end{array}$ & $\begin{array}{l}\text { Triggers Responding stage } \\
\text { in parallel }\end{array}$ \\
\hline & Updating & $\begin{array}{l}\text {... update consumers about ongoing } \\
\text { developments }\end{array}$ & $\begin{array}{l}\text { Triggers Responding stage } \\
\text { in parallel }\end{array}$ \\
\hline
\end{tabular}

Deploying

Business stakeholders decide about the duration and timing of... 


\begin{tabular}{lll}
\hline Listening & $\begin{array}{l}\text {... listening to consumer conversations to } \\
\text { identify potential for innovation } \\
\text { improvements }\end{array}$ & Triggers Listening stage \\
Updating & $\begin{array}{l}\text {... updating consumers about innovation roll- } \\
\text { out }\end{array}$ & Triggers Responding stage \\
\hline
\end{tabular}

Table 3. Explanation and implications of the decisions taken in individual process stages

\subsubsection{Listening stage}

The first stage of the retailer's social media-driven innovation process is the Listening stage (Soukhoroukova, Spann, \& Skiera, 2012), during which the retailer screens consumer-to-consumer and consumer-to-brand conversations on social media to identify the ones that provide potential for innovation. During Listening, all social media conversation formats are taken into consideration, as explained by one of the social media managers: "It can be anything, really. Most of it is predominately seeking conversation between customers and [our subsidiary] or other customers. So that is usually the copy [brief, guidance]. Things that also come up in that kind of perspective are images, videos, GIFs [graphic interchange format files], kind of, different formats in that space. But really it's the conversation between [our subsidiary] and the customer that gets the most leverage and the most insight that we then use for innovative purposes."

The retailer has one social media manager for each of its subsidiaries who listens to and decides how to respond to respective consumer conversations, thereby acting as organizational gatekeepers (Tushman \& Katz, 1980; Whelan et al., 2010). The social media managers used a number of social media listening tools (e.g., Socialbakers, Social Dot Com, Sysomos, Lithium) that differ across subsidiaries plus external vendors to assist them with finding and analyzing relevant consumer conversations. The volume of analyzed conversations is on average between 250 and 400 comments per day for each of the three subsidiaries. However, in the case of media exposure, conversations relevant to the retailer can spike up to $1500-5000$ comments per day for each subsidiary. Hence, it is important for social media managers to filter out noise and to make decisions about which conversations provide opportunities for innovation and should be progressed further.

The social media managers evaluate the innovation potential of consumer conversations and decide independently on how to address them based on whether conversations are trending, aligning, or need isolating. Trending is defined by the 
volume of engagement around a specific content. As one social media manager explained trending, "if it is feedback we receive frequently and from a high volume of consumers, then it puts the urgency there to do something about it". Aligning is defined by the degree of alignment between the conversations and the respective subsidiary's strategy. As one social media manager explained: "We have a policy where all customer queries are responded to. So, everyone will get a response, but then internally whether we actually have actioned off the back of that I guess comes down to kind of the [subsidiary] objectives, so you know, does it fall into something that is within you know, a growth area for us, or a priority area for us." Lastly, isolating is defined by the extent of actors that are potentially concerned by social media conversations. Conversations that have been identified as trending or aligning enter the next stage of the innovation process, Assessing, because they have a high potential to trigger consumer-oriented innovation at the retailer. We will refer to these conversations as 'ideas' in the following. By contrast, isolating conversations do not pass the Listening stage because they have only limited potential to make a positive impact on the retailer's consumer orientation at large.

\subsubsection{Responding stage}

Responding is a recurring, parallel process stage that can be triggered in any of the main process stages from Listening to Assessing to Converting to Deploying. As already indicated in one of the social media managers' statements, the retailer has a policy that social media managers need to respond to all conversations on Facebook. As a result, social media managers create logs for ideas when they enter the Assessing stage, track their internal progress, and provide updates about the internal development status throughout the social media-driven innovation process to consumers on social media.

By contrast, in the case of isolating conversations that do not pass the filtering criteria of the Listening stage, social media managers directly respond on social media to close the conversation and inform relevant organization internal stakeholders if necessary. A specific example of social media managers Responding to conversations that have been identified as isolating is the following: "Hi Fred, thanks for the suggestion. We're always aiming to cater towards our customers expectation. We regularly review our range to ensure that what we offer aligns with what our customers are looking for. Unfortunately, space restrictions and the buying attitudes 
of our customers sometimes means that products are removed from our stores. However, all customer feedback are taken on board so rest assure that our team is aware of your comments regarding the change. Thanks for getting in touch and we hope to see you in our stores again soon Fred." Another example from our extracted Facebook conversations showed that a small number of consumers raised sustainability-related ideas such as removing the need to wrap fruit or/and vegetables in plastic and supplying a certain environmentally friendly product. In these instances, the consumers received a reply from the retailer, directing them to one of the retailer's homepages where they could read more about the retailer's sustainability commitments and practices. Hence, after deciding for isolating, social media managers respond to consumers but do not action the ideas further internally. Importantly, as our interviews with consumers showed, responding to their conversations and providing them with updates is a key activity for retailers to maintain positive consumer relationships. Almost all of the interviewed consumers (40) expected retailers to take action if they provide retailers with comments. Specifically, consumers expect retailers to acknowledge conversations publicly and to update the public on resulting actions taken. Moreover, about half of the consumers provided recent examples of ideas or complaints that they had posted on social media. Similarly, about half of the consumers knew specific examples of when a retailer (or manufacturer) had responded to another consumer's comment, and also when a retailer (or manufacturer) had not responded to another consumer's comment that they thought warranted a response. Hence, due to the broad visibility of conversations on social media, whether and how retailers respond to a consumer not only influences their relationship with this specific consumer but also other consumers who observe this conversation (or its absence).

\subsubsection{Assessing stage}

In the Assessing stage, ideas that have been identified through the filtering of consumers' social media conversations are passed on from the social media managers to the relevant internal stakeholders such as department leads or store managers, or external stakeholders such as vendors who supply products or provide complementary services. These stakeholders then become the ideas' business owners and have to independently make one of three decisions based on criteria such as its feasibility, impact on consumers, and required organizational changes: actioning, pausing, or rejecting. An idea enters the next stage of the social media- 
driven innovation process-Converting - if business owners decide for actioning; the decision is postponed and respective social media conversations go back into the Listening stage for further observation if business owners decide for pausing; and the idea is not pursued further if business owners decide for rejecting.

\subsubsection{Converting stage}

All ideas that enter the Converting stage are getting implemented. Business owners typically form a project team that takes over the idea implementation. Ideas that can directly be actioned and require little clarification are directly implemented by the project team without further external input. However, the project team can take the following three non-mutually exclusive decisions to facilitate the implementation via social media: engaging, listening, and updating.

Engaging refers to when the project team decides to engage with consumers for idea implementation. This approach is usually taken if consumer ideas are ambiguous and/or further information is needed to shape and refine an idea (Delerue \& Vuori, 2012). In this case, social media managers either respond to social media conversations with a comment that includes an URL link or engage directly with the consumer replying to the original post. The URL link allows consumers to engage in private conversations with the social media managers and includes the retailer's customer services support phone number. The URL link is mostly provided for consumer ideas or problems that have the risk of triggering negative conversations. If conversations are expected to be positive, engagement with the consumer using public social media conversations is more likely. For example, the extracted Facebook data showed how the retailer directly engaged a consumer after the consumer posted a comment on Facebook highlighting that the new loyalty program was not providing them with any rewards. To understand more about the consumer's preferences for the loyalty program the social media manager replied: "We completely understand Margaret! What would be your top five items to have on offer? We're always keen to hear what our members think." In turn, after the consumer provided the requested feedback, the social media followed the updating procedure and informed her about the next step: "Thanks for that Margaret, we're working hard to bring our members even more offers like this. We appreciate the feedback and we'll share this with the team. Cheers!" 
Listening refers to when the project team decides to trigger a parallel process focused on understanding what consumers at large say about a specific topic to get a better understanding of how an idea could be implemented (Brandel, 2010; Weiguo \& Gordon, 2014). This parallel process is handed over to social media managers and starts again from the Listening stage. During listening, social media managers actively search for and analyze consumer conversations pertaining to this topicboth inside and outside the retailer's own social media presence. This is done internally using their social media listening technology, and also assisted by the retailer's external vendors' social listening services. One social media manager explained Listening to consumer sentiment on social media "So for instance, it might be avocados, if they're a particular kind of product or key word that we're actually searching for at that period time, if it's important to the business - we actually pool through conversations that people are having or content that the people are using into broader reporting perspectives, and kind of, those insights then feed into the things that we say and the things that we do."

Lastly, Updating refers to targeted announcements about the progress of idea implementations, which project teams can use at any time to inform consumers and to promote upcoming idea launches.

The Converting stage ends with an innovation such as a transformed offering or a service that is better aligned with consumers' expectations and demands, which are then rolled-out in the Deploying stage. Most of these innovations can be considered as improvement and incremental service innovations. Table 4 provides selected examples of innovations by the retailer that made it through the converting stage and resulted from consumer conversations on social media. The project teams often worked directly with suppliers to implement many of these innovation ideas such as with farmers in case of the increased range of free-range eggs innovation to help farmers adapt their products to consumer demands.

\subsubsection{Deploying stage}

Deploying is the last stage of the process. Once an idea has been converted into an innovation, it gets deployed in business operations by the dedicated national operations teams. These teams decide on updating consumers in terms of when and how to announce the innovation implementation on social media. As the retailer has a commitment to create value for consumers and relies heavily on consumer 
feedback, the retailer continues listening to consumer conversations even after implementations for a period of time that is decided by the business owners. During this time, related conversations automatically qualify as aligning with the retailer's strategic priorities. This approach allows the retailer to fine tune innovations and to learn from their deployment. For example, after the free-fruit for children initiative was launched and implemented in stores the social media manager actively monitored related consumer comments on social media. The social media manager described how he explained this approach: "I pointed [out earlier the] free-fruit for kids as an example of where we've taken social feedback and [then] used that [feedback] to manage the actual rollout and what customers think about it." As part of the Listening stage that has been triggered by the deploying stage, the social media managers create reports and innovation logs containing relevant social media conversations for the subsidiaries. These reports are then shared with the relevant business owners inside the subsidiaries for their Assessing on a weekly basis.

\begin{tabular}{lll}
\hline Subsidiary & & \multicolumn{1}{c}{ Innovation } \\
\hline Grocery & - & Implementation of a free-fruit for children initiative within stores \\
& - & Digitalization of the retailer's magazine \\
& - & Website changes including improved search and navigation functions and \\
& - & Adding of functionality to the mobile app \\
& - & Increased range of free-range eggs \\
& - & Switch to a more ethical produce sourcing \\
& - & Re-instantiation of product removal \\
& - & Adaptation of marketing campaigns to consumer demands in real time \\
& - & Earlier store opening hours in requested store location \\
\hline Liquor & - & Deployment of new stores in requested locations \\
& - & Improvements of staff processes related to in-store consumer service \\
& - & Real-time adaptation of terms and conditions of offers that caused confusion \\
& - & New liquor product ranges in requested store locations \\
& - & Addition of complementary products such as lemons and limes \\
\hline Loyalty & - & Heightened awareness of consumer loyalty and reward preferences \\
& - & Transformation of the loyalty program tailored to expressed consumer \\
& & preferences
\end{tabular}

Table 4. Examples of innovations resulting from consumer conversations on social media

\subsection{Vignette: The social media-driven innovation capability in action}

In the following we describe a specific and detailed episode of how the social mediadriven innovation process was used by the case retailer for innovation purposes.

Prior to our research in December 2015, the retailer conducted a major transformation of its loyalty program by changing the conditions in which consumers were rewarded in return for their loyalty. These changes resulted in a public outcry by 
consumers who could not see the value of the new conditions for them. At the time, consumers started to post Problems about the new loyalty program on social media and Suggestions for how the retailer could better tailor the loyalty program to their needs. Our conversation analysis revealed high volumes of conversations about the retailers' change in their loyalty program during late 2015 and early 2016 . For example, a Facebook post in December 2015, just after the loyalty change, showed how the new loyalty program was providing less returns to a particular consumer. This consumer did not purposefully post to support the retailer's innovation activities but rather to voice their disappointment. The post went viral and received more than 50,000 likes, 7000 comments, and 4500 shares of other consumers in only three days. With many consumers discussing the loyalty program changes on social media it was identified as a Trending conversation by the social media manager in the Listening stage. Next, entering the Assessing stage, the conversation details were forwarded to the loyalty department which decided for Actioning. Subsequently, the loyalty department formed a team in the Converting stage to revamp the loyalty program. This newly formed team decided to provide consumers with a choice on how they could use their loyalty points, which was identified by listening to consumer conversations on social media over a 12-month period leading up to the previous program changes. Subsequently, the team decided to update consumers about the future changes and began Converting with the purpose to build new business processes and to make software changes that supported the future loyalty program. During Converting, the team decided to continue listening to the ongoing conversations and making changes to the revised loyalty program until it was ready to be rolled out. During the final phase of Converting, the team decided to update consumers about the upcoming change via both social and traditional media. The whole process, from the retailer subsidiary identifying a trending conversation during Listening in December 2015 to Converting the new loyalty program in August 2016 took eight months. The social media managers continued Listening to consumer comments about the innovation implementation during and after Deploying with the purpose to further adapt the program based on relevant sentiment. To this day the loyalty program is still being adapted on an ongoing basis based on Listening to consumer conversations on social media.

While the case retailer was committed to meeting their consumer demands on social media, there were instances when the case retailer could not adopt consumer 
suggestions or resolve consumer complaints mostly because of financial, technical or legal ramifications. For example, one Suggestion by consumers was to store loyalty points as credit on their loyalty card that they could use when needed, as opposed to the automatic deduction once the specified credit limit was reached. The social media managers identified this suggestion during the Listening stage as trending, passed it to the loyalty team for Assessing, and updated consumers on social media about this action. During the Assessing stage, however, this idea was rejected by the loyalty team because it did not align with the retailer's strategy: consumers' accrual of loyalty credits would have required the retailer to reserve funds for future consumer purchases and overall increased the retailer's financial liability, especially if consumers would accrue a large amount of credit. Hence, the loyalty team decided for rejecting the idea during the Assessing stage, which triggered social media managers Responding to consumers and updating them about this decision.

\section{Discussion}

\subsection{Summary of Findings and Insights}

Our study provides a detailed, inductive analysis of how one of the worlds' largest retailers developed a capability to leverage consumer conversations that are publicly available on social media for product and service innovation-independent of whether the conversations have been created purposefully for innovation activities or not. We identified three types of conversations-problems, questions, and suggestions-that bear the potential to provide innovation impetus, and we developed a model with four stages of an end-to-end open innovation processlistening, assessing, converting, and deploying-through which consumer conversations traverse into innovation at the retailer, and one stage-respondingthat runs in parallel and can be executed at any time.

One key insight of our study is contrary to what large shares of existing research assume and focus on: digital technologies not only enable individual process stages or become the outcome (Barrett et al., 2015; Lyytinen, Yoo, \& Boland, 2016; Williams, Chatterjee, \& Rossi, 2008) of product and service innovation, but can also act as external enablers of the holistic innovation process (Davidsson, Recker, \& von Briel, 2019). As we demonstrate, enabling digital technologies that provide innovation-relevant information, such as social media platforms, can trigger and shape both the innovation process and its outcomes, even for non-digital products 
and services (such as sustainable produce sourcing). Our case thus shows that, when organizations are aware of digital technologies in their reach that can act as external enablers, they can build capabilities to harvest, absorb, and integrate this enablement into their own internal product and service innovation processes.

A second insight is that we demonstrate how the microfoundations of the social media-driven innovation capability are socio-technical assemblages, requiring both technological investment (e.g., into social media listening tools (Brandel, 2010)) and the setup of dedicated roles and structures (e.g., roles for social media analytics, brokering and implementation). Our work yields a process model that can guide the development and implementation of an innovation work system in organizations. It also demonstrates how important both the technical and social subsystem are: social media listening technologies could scrape and filter potential innovation ideas, but without a brokering role dedicated to conversion, these ideas would never be implemented (Patroni, Von Briel, \& Recker, 2016). In the same vein, product and service innovation managers by themselves would never be able to parse, assess, or filter the volume and magnitude of content generated through social media technologies without the help of technologies for listening and analyzing these data.

A third insight stems from our observations that the types of innovation pursued and ultimately deployed through social media-driven innovation-at least in the focal case-are usually incremental rather than transformational (Nagji \& Tuff, 2012). A likely reason is that social media conversations are often focused on current experiences with extant products or services, that is, they are grounded in the here and now rather than concerned with "what might be" (Simon, 1996, p. xii). As a result, social media-driven innovation appears as a reactive and problem-focused mode of innovation instead of a proactive and design-led mode (Gruber, de Leon, George, \& Thompson, 2015).

\subsection{Contributions and Implications}

Our study makes three main contributions to the literature. First, by identifying social media-driven innovation as an important new IT-enabled capability and unpacking the actions, interactions, and decisions of individuals that underlie it, we contribute to the literature on IT capabilities (Kim et al., 2011; Rai \& Tang, 2010; Saldanha et al., 2017), with a specific focus on social media as one such capability. Prior research has shown that consumer conversations on social media can have a rapid and 
substantial impact on organizational outcomes such as sales and stock valuations (Deng et al., 2018; Luo \& Zhang, 2013; Oh et al., 2017). Research has also shown that the capability to engage with consumers via social media can positively influence organizational outcomes (Candi et al., 2018; Lehrer, Wieneke, Vom Brocke, Jung, \& Seidel, 2018). However, little has been known about how organizations actually deal with and benefit from the vast amount of consumer conversations that take place on social media and how exactly social media can spawn a new organizational capability. Our study provides in-depth insights into the process of how an organization uses publicly accessible consumer conversations on social media to successfully drive organizational innovation. Specifically, our study shows that consumer conversations can provide important impetus for organizational innovation and potentially lead to a continuous dialog between consumers and organizations throughout the entire innovation process. Our study thereby broadens the focus of existing social media research and shifts attention from the implications of organizational responses to consumer conversations (or the absence thereof) (Gallaugher \& Ransbotham, 2010; Gunarathne et al., 2018) to the value of dialog and conversation with consumers for organizational outcomes.

Moreover, We heed calls for a focus on the microfoundations of organizational capabilities (Bogers et al., 2017; Felin et al., 2012; Felin et al., 2015)—that is, the role of individuals and their actions and interactions that give rise to them. By shedding light not only on the sequence of actions underlying the social media-driven innovation capability but also on who performs actions, who takes decisions, and how decisions influence the trajectory of the overall process, we provide important insights into the microfoundations of this important IT capability. Specifically, our findings reveal that the interactions between social media managers who leverage digital technologies to extract knowledge from consumer conversations and business stakeholders who act on this knowledge give rise to the social media-driven innovation capability, which, in turn, fosters innovation at the organizational level. Our study thus lays a foundation for future research on IT capabilities to understand and study sources of innovation heterogeneity among organizations.

Second, by analyzing how one of the world's largest retailers innovates based on consumer conversations on social media that have not necessarily been created for innovation purposes, we contribute to the understanding of how digital technologies can trigger, enable, and shape open innovation (Lusch \& Nambisan, 2015; Nambisan 
et al., 2017). Digital technologies have been the focus of open innovation research for a long time (Dissanayake et al., 2018; West \& Bogers, 2014). However, most of this research has been based on the implicit or explicit assumption that digital technologies are purposefully developed and deployed by organizations to collaborate with external innovators and focused on the early stages of the innovation process. Our study broadens this perspective as we show that digital technologies such as social media can trigger, enable, and shape organizational innovation even if neither the knowledge nor technology was created for innovation purposes and even if external actors do not actively collaborate.

Moreover, while also our study points toward the enabling potential of digital technologies in the early stages of the innovation process, it illustrates that digital technologies can augment any stage of the innovation process to ultimately influence organizational innovation outcomes. This is an important insight as it demonstrates that digital technologies can go beyond being mere enablers or outcomes and instead give rise to entirely new innovation processes. We have elaborated one process model that was being implemented, and used effectively, in the case we studied. Future research could investigate how other organizations leverage consumer conversations on social media in their open innovation process to test and refine our process model if necessary. Future research could also explore other variants of the process model as used by other organizations, or enabled by digital technologies other than social media (e.g., customer analytics), to see if our model has validity beyond the domain and technology we focused on.

Third, by examining how consumer conversations on social media provide initial input for, and traverse through, organizational processes to ultimately result in service innovation, our study responds to calls for better understanding the end-to-end open innovation process, especially in service contexts (Randhawa et al., 2016; West et al., 2014). The service sector is an important element in the global environment and service innovation differs from product innovation. However, open innovation in the service sector has received limited attention from researchers so far. One of the reasons for this might be that it is often more difficult to quantify service innovation. For example, traditional measures of innovation that are used in product innovation contexts such as R\&D spending or patents cannot necessarily be applied in service innovation contexts because respective organizations often have no R\&D departments and services are usually not patentable (Hipp \& Grupp, 2005; Nijssen et 
al., 2006). This was also the case in our study, where the focal organization had no formal R\&D functions even though it was one of the world's largest retailers. By using a qualitative research approach, we were able to capture and analyze service innovations such as the switch to more ethical produce sourcing that might have been difficult to capture and analyze otherwise. Hence, our study provides an original and insightful empirical account of the end-to-end open innovation process in service contexts and the insights provided in this paper can inform future studies that aim to develop quantitative measures for service innovation.

Finally, our study also contributes to practice. We identify the process through which one of the world's largest retailer leverages vast amounts of publicly available and exponentially growing social media conversations for innovation. Hence, our process model can serve as guidance for other organizations that want to tap into the potential of publicly accessible consumer conversations on social media for their innovation efforts. Specifically, as consumer conversations on social media influence consumer behavior across an increasing number of industry sectors, we believe that this guidance is valuable for a broad range of firms and from various industry sectors. Moreover, because we identify the overarching macro-level process, its underlying microfoundations, and provide real-world examples of the process in action, we are confident that our work provides actionable knowledge for practitioners.

\subsection{Limitations}

As it is the case with any empirical study, ours has its limitations. First, our research is based on one organization in the retail sector and three of its subsidiaries. This may limit the generalizability of our findings and provides opportunities for future research to examine whether social media-driven innovation might differ between organizations, industry sectors, or innovation types. Second, our research is to a large extent based on primary data gathered from social media managers in the organization's subsidiaries, who were the key individuals responsible for actioning innovation based on external social media inside the organization. The self-reported nature of these data and the relatively small sample size introduce the risk of biased interpretations. To address this risk, we triangulated the data with data from social media and a senior executive with subject matter expertise. However, future research might want to use additional data sources such as improvements of service quality to empirically evaluate innovation outcomes. Third, since the organizational use of publicly available social media conversations for innovation purposes had not 
received much attention from researchers, our theory development had to be largely grounded in data rather than the existing literature. Fourth, our qualitative, inductive research relied on our subjective interpretation of social media data during coding. We tried to mitigate subjectivity by making the link between data and our findings as plausible and reproducible as possible. Among us, we also engaged continuously in a dialectic process of challenging our own interpretations through dialog and suspicion (Klein \& Myers, 1999). Still, future research could employ complementary objective methods such as text and web mining that can handle large volumes of social media data to test and refine our model (Abbasi et al., 2018). Fifth, consumers and competitors could potentially use social media to mislead organizations such as in the context of fraudulent behavior or targeted misinformation. It was neither in our scope nor possible for us to identify whether such activities took place with regard to the focal retailer, but future research might find it worthwhile to investigate malevolent activities in the context of social media-driven innovation.

\section{Conclusion}

We provide insights into the microfoundations of a key capability of one of the world's largest retailers: the capability to leverage consumer conversations on social media to open up its innovation processes. We identified three types of conversationsproblems, questions, and suggestions - that bear the potential to provide innovation impetus. Our model of the end-to-end open innovation process describes four stages-filtering, assessing, converting, and deploying-through which consumer conversations on social media become innovations at the retailer, plus one stageresponding - that runs in parallel and can be executed at any time. This end-to-end open innovation process model is contextualized to social media as an enabling digital technology and has been developed in the service innovation context. We hope our process model provides inspiration for future research on the role of digital technologies in enabling service innovation and open innovation at large. We also hope that our process model provides a valuable framework for practitioners who want to tap into publicly available data for their innovation efforts. 


\section{References}

Abbasi, A., Zhou, Y., Deng, S., \& Zhang, P. (2018). Text analytics to support sensemaking in social media: A language-action perspective. MIS Quarterly, 42(2), 427-464.

Barrett, M., Davidson, E., Prabhu, J., \& Vargo, S. L. (2015). Service innovation in the digital age: Key contributions and future directions. [Article]. MIS Quarterly, 39(1), 135-154.

Bayus, B. L. (2013). Crowdsourcing new product ideas over time: An analysis of the dell ideastorm community. Management Science, 59(1), 226-244.

Bharadwaj, A. (2000). A resource-based perspective on information technology capability and firm performance: An empirical investigation. MIS Quarterly, 24(1), 169-196.

Bhatt, G. D., \& Grover, V. (2005). Types of information technology capabilities and their role in competitive advantage: An empirical study. Journal of Management Information Systems, 22(2), 253-277.

Bogers, M., Foss, N. J., \& Lyngsie, J. (2017). The 'human side' of open innovation: The role of employee diversity in firm-level openness. Research Policy, 47(1), 218-231.

Bolton, G. E., Katok, E., \& Ockenfels, A. (2004). How effective are electronic reputation mechanisms? An experimental investigation. Management Science, 50(11), 1463-1613.

Brandel, M. (2010). Are you listening? [Article]. Computerworld, 44(13), 12-15.

Cameron, M. (2014). Australian retailers finally get digital and they're sick of the word omnichannel as you are Retrieved 15 July, 2015, 2015, from http://www.afr.com/business/media-and-marketing/australian-retailers-finallyget-digital-and-theyre-as-sick-of-the-word-omnichannel-as-you-are-20140825jy9ze

Candi, M., Roberts, D. L., Marion, T., \& Barczak, G. (2018). Social strategy to gain knowledge for innovation. British Journal of Management, 29(4), 731-749.

Charmaz, K. C. (2006). Constructing grounded theory: A practical guide through qualitative analysis. London, England: Sage.

Chesbrough, H. W. (2003). The era of open innovation. MIT Sloan Management Review, 44(3), 35-41.

Chesbrough, H. W., \& Brunswicker, S. (2014). A fad or a phenomenon?: The adoption of open innovation practices in large firms. Research-Technology Management, 57(2), 16-25.

CIA. (2017). The world fact book Retrieved 10th October, 2017, 2017, from https://www.cia.gov/library/publications/the-world-factbook/

Constantinides, E., Romero, C. L., \& Boria, M. A. G. (2008). Social media: A new frontier for retailers? European Retail Research, 22(27), 1-28. doi: 10.1007/978-3-8349-8099-1_1

Corbin, J. M., \& Strauss, A. L. (2015). Basics of qualitative research: Techniques and procedures for developing grounded theory (Vol. Fourth). Thousand Oaks, California: SAGE Publications.

Davidsson, P., Recker, J., \& von Briel, F. (2019). External enablement of new venture creation: A framework. Academy of Management Perspectives, forthcoming.

Delerue, H., \& Vuori, M. (2012). Exploring uses of social media in a global corporation. Journal of Systems and Information Technology, 14(2), 155-170. 
Deloitte. (2017). Global powers of retailing 2017 the art and science of customers Retrieved 10th October, 2017, 2017, from https://www2.deloitte.com/content/dam/Deloitte/global/Documents/consumerindustrial-products/gx-cip-2017-global-powers-of-retailing.pdf

Deng, S., Huang, Z. J., Sinha, A. P., \& Zhao, H. (2018). The interaction between microblog sentiment and stock return: An empirical examination. MIS Quarterly, 42(3), 895-917.

Denzin, N. K. (2001). Interpretive interactionism (2nd ed.). Newbury Park, California: Sage.

Dewan, S., \& Ramaprasad, J. (2014). Social media, traditional media, and music sales. MIS Quarterly, 38(1), 101-121.

Dissanayake, I., Zhang, J., Yasar, M., \& Nerur, S. P. (2018). Strategic effort allocation in online innovation tournaments. Information \& Management, 55(3), 396-406.

Dong, J. Q., \& Wu, W. (2015). Business value of social media technologies: Evidence from online user innovation communities. Journal of Strategic Information Systems, 24(2), 113-127.

Duan, W., Gu, B., \& Whinston, A. B. (2008). Do online reviews matter? - an empirical investigation of panel data. Decision Support Systems, 45(4), 1007-1016.

Edvardsson, B., Haglund, L., \& Mattsson, J. (1995). Analysis, planning, improvisation and control in the development of new services. International Journal of Service Industry Management, 6(2), 24-35.

Eisenhardt, K. M. (1989). Building theories from case study research. Academy of Management Review, 14(4), 532-550.

Facebook. (2016). Facebook stats Retrieved 4th February, 2016, 2016, from http://newsroom.fb.com/company-info/

Felin, T., Foss, N. J., Heimeriks, K. H., \& Madsen, T. L. (2012). Microfoundations of routines and capabilities: Individuals, processes, and structure. Journal of Management Studies, 49(8), 1351-1374.

Felin, T., Foss, N. J., \& Ployhart, R. E. (2015). The microfoundations movement in strategy and organization theory. Academy of Management Annals, 9(1), 575632.

Füller, J., Hutter, K., \& Faullant, R. (2011). Why co-creation experience matters? Creative experience and its impact on the quantity and quality of creative contributions. R\&D Management, 41(3), 259-273. doi: 10.1111/j.14679310.2011.00640.x

Füller, J., Mühlbacher, H., Matzler, K., \& Jawecki, G. (2009). Consumer empowerment through internet-based co-creation. Journal of Management Information Systems, 26(3), 71-102. doi: 10.2753/MIS0742-1222260303

Gallaugher, J., \& Ransbotham, S. (2010). Social media and customer dialog management at starbucks. MIS Quarterly Executive, 9(4), 197-212.

Gallouj, F., \& Weinstein, O. (1997). Innovation in services. Research Policy, 26(4), 537-556. doi: 10.1016/S0048-7333(97)00030-9

Gioia, D. A., Corley, K. G., \& Hamilton, A. L. (2013). Seeking qualitative rigor in inductive research. Organizational Research Methods, 16(1), 15-31.

Glynn, M. A. (1996). Innovative genius: A framework for relating individual and organizational intelligences to innovation. Academy of Management Review, 21(4), 1081-1111.

Gruber, M., de Leon, N., George, G., \& Thompson, P. (2015). Managing by design. Academy of Management Journal, 58(1), 1-7. 
Gunarathne, P., Rui, H., \& Seidmann, A. (2018). When social media delivers customer service: Differential customer treatment in the airline industry MIS Quarterly, 42(2), 489-520.

Habersang, S., Küberling-Jost, J., Reihlen, M., \& Seckler, C. (2019). A process perspective on organizational failure: A qualitative meta-analysis. Journal of Management Studies, 56(1), 19-56.

Hipp, C., \& Grupp, H. (2005). Innovation in the service sector: The demand for service-specific innovation measurement concepts and typologies. Research Policy, 34(4), 517-535. doi: 10.1016/j.respol.2005.03.002

Joshi, K. D., Chi, L., Datta, A., \& Han, S. (2010). Changing the competitive landscape: Continuous innovation through it-enabled knowledge capabilities. Information Systems Research, 21(3), 472-495.

Kane, G. C., Alavi, M., Labianca, G., \& Borgatti, S. P. (2014). What's different about social media networks? A framework and research agenda. [Article]. MIS Quarterly, 38(1), 275-304.

Kaplan, A. M., \& Haenlein, M. (2010). Users of the world, unite! The challenges and opportunities of social media. Business Horizons, 53(1), 59-68.

Kietzmann, J. H., Hermkens, K., McCarthy, I. P., \& Silvestre, B. S. (2011). Social media? Get serious! Understanding the functional building blocks of social media. Business Horizons, 54(3), 241-251. doi: http://dx.doi.org/10.1016/j.bushor.2011.01.005

Kim, G., Shin, B., Kim, K. K., \& Lee, H. G. (2011). It capabilities, process-oriented dynamic capabilities, and firm financial performance. Journal of the Association for Information Systems, 12(7), 487-517.

Klein, H. K., \& Myers, M. D. (1999). A set of principles for conducting and evaluating interpretive field studies in information systems. MIS Quarterly, 23(1), 67-94.

Lehrer, C., Wieneke, A., Vom Brocke, J., Jung, R., \& Seidel, S. (2018). How big data analytics enables service innovation: Materiality, affordance, and the individualization of service. Journal of Management Information Systems, 35(2), 424-460.

Leonardi, P. M. (2014). Social media, knowledge sharing, and innovation: Toward a theory of communication visibility. Information Systems Research, 25(4), 796816. doi: 10.1287/isre.2014.0536

Locke, E. A. (2007). The case for inductive theory building. Journal of Management, 33(6), 867-890.

Love, J. H., Roper, S., \& Bryson, J. R. (2011). Openness, knowledge, innovation and growth in uk business services. Research Policy, 40(10), 1438-1452. doi: 10.1016/j.respol.2011.05.016

Luo, J., Fang, M., \& Zhang, H. (2016). Information technology, cross-channel capabilities, and managerial actions: Evidence from the apparel industry. Journal of the Association for Information Systems, 17(5), 308-327.

Luo, X., \& Zhang, J. (2013). How do consumer buzz and traffic in social media marketing predict the value of the firm? Journal of Management Information Systems, 30(2), 213-238.

Lusch, R. F., \& Nambisan, S. (2015). Service innovation: A service-dominant logic perspective. MIS Quarterly, 39(1), 155-175.

Lyytinen, K., Yoo, Y., \& Boland, R. J. (2016). Digital product innovation within four classes of innovation networks. Information Systems Journal, 26(1), 47-75.

Majchrzak, A., \& Malhotra, A. (2013). Towards an information systems perspective and research agenda on crowdsourcing for innovation. JOURNAL OF 
STRATEGIC INFORMATION SYSTEMS, 22(4), 257-268. doi: 10.1016/j.jsis.2013.07.004

Mason, M. (2015). Why retailers are struggling to pick up steam Retrieved 15th July, $2015, \quad 2015$, from http://www.smh.com.au/business/the-economy/whyretailers-are-struggling-to-pick-up-steam-20150219-13jhbe.html

Matook, S., Brown, S. A., \& Rolf, J. (2015). Forming an intention to act on recommendations given via online social networks. [Empirical Research]. Eur J Inf Syst, 24(1), 76-92. doi: 10.1057/ejis.2013.28

McKinley, W., Latham, S., \& Braun, M. T. (2014). Organizational decline and innovation: Turnarounds and downward spirals. Academy of Management Review, 39(1), 88-110.

Mention, A.-L. (2011). Co-operation and co-opetition as open innovation practices in the service sector: Which influence on innovation novelty? Technovation, 31(1), 44-53. doi: https://doi.org/10.1016/j.technovation.2010.08.002

Miles, M. B. (1990). New methods for qualitative data collection and analysis: Vignettes and pre-structured cases. International Journal of Qualitative Studies in Education, 3(1), 37-51.

Miles, M. B., \& Huberman, M. (1994). Qualitative data analysis (2nd ed.). Thousand Oaks, California: Sage.

Mina, A., Bascavusoglu-Moreau, E., \& Hughes, A. (2014). Open service innovation and the firm's search for external knowledge. RESEARCH POLICY, 43(5), 853-866. doi: 10.1016/j.respol.2013.07.004

Mithas, S., Ramasubbu, N., \& Sambamurthy, V. (2011). How information management capability influences firm performance. MIS Quarterly, 35(1), 237-256.

Myers, M. D. (2009). Qualitative research in business and management. Thousand Oaks, California: Sage.

Myers, M. D. (2013). Qualitative research in business \& management. London: SAGE.

Nagji, B., \& Tuff, G. (2012). Managing your innovation portfolio. Harvard Business Review, 90(5), 66-74.

Nambisan, S., Lyytinen, K., Majchrzak, A., \& Song, M. (2017). Digital innovation management: Reinventing innovation management research in a digital world. MIS Quarterly, 41(1), 223-238.

Nijssen, E. J., Hillebrand, B., Vermeulen, P. A. M., \& Kemp, R. G. M. (2006). Exploring product and service innovation similarities and differences. International Journal of Research in Marketing, 23(3), 241-251. doi: 10.1016/j.ijresmar.2006.02.001

Noyes, D. (2017). The top 20 valuable facebook statistics Retrieved 23rd Sep 2017, 2017, from https://zephoria.com/top-15-valuable-facebook-statistics/

Oh, C., Roumani, Y., Nwankpa, J. K., \& Hu, H.-F. (2017). Beyond likes and tweets: Consumer engagement behavior and movie box office in social media. Information \& Management, 54(1), 25-37.

Olsen, N. V., \& Christensen, K. (2015). Social media, new digital technologies and their potential application in sensory and consumer research. Current Opinion in Food Science, 3, 23-26. doi: http://dx.doi.org/10.1016/j.cofs.2014.11.006

Patroni, J., Von Briel, F., \& Recker, J. (2016). How can enterprise social media use facilitate innovation? An exploratory study in the retail industry. IT Professional, 18(6), 34-41. 
Phan, M., Thomas, R., \& Heine, K. (2011). Social media and luxury brand management: The case of burberry. Journal of Global Fashion Marketing, 2(4), 213-222. doi: 10.1080/20932685.2011.10593099

Piller, F. T., \& Walcher, D. (2006). Toolkits for idea competitions: A novel method to integrate users in new product development. $R$ and $D$ Management, 36(3), 307-318. doi: 10.1111/j.1467-9310.2006.00432.x

Rai, A., Pavlou, P. A., Im, G., \& Du, S. (2012). Interfirm it capability profiles and communications for cocreating relational value: Evidence from the logistics industry. MIS Quarterly, 36(1), 233-262.

Rai, A., \& Tang, X. (2010). Leveraging it capabilities and competitive process capabilities for the management of interorganizational relationship portfolios. Information Systems Research, 21(3), 516-542.

Randhawa, K., Wilden, R., \& Hohberger, J. (2016). A bibliometric review of open innovation: Setting a research agenda. Journal of Product Innovation Management, 33(6), 750-772.

Rayna, T., \& Striukova, L. (2015). Open innovation 2.0: Is co-creation the ultimate challenge? International Journal of Technology Management, 69(1), 38-53.

Recker, J., Malsbender, A., \& Kohlborn, T. (2016). Learning how to effectively use enterprise social networks as innovation platforms. IT Professional, 18(2), 2-9.

Roberts, D. L., Piller, F. T., \& Lüttgens, D. (2016). Mapping the impact of social media for innovation: The role of social media in explaining innovation performance in the pdma comparative performance assessment study. Journal of Product Innovation Management, 33(S1), 117-135.

Saldanha, T. J., Mithas, S., \& Krishnan, M. S. (2017). Leveraging customer involvement for fueling innovation: The role of relational and analytical information processing capabilities. MIS Quarterly, 41(1), 367-396.

Schlagwein, D., \& Bjørn-Andersen, N. (2014). Organizational learning with crowdsourcing: The revelatory case of lego. Journal of the Association for Information Systems, 15(11), 754-778.

Schlagwein, D., \& Hu, M. (2017). How and why organisations use social media: Five use types and their relation to absorptive capacity. Journal of Information Technology, 32(2), 194-209.

Simon, H. A. (1996). The sciences of the artificial (3rd ed.). Cambridge, Massachusetts: MIT Press.

Sorescu, A., Frambach, R. T., Singh, J., Rangaswamy, A., \& Bridges, C. (2011). Innovations in retail business models. Journal of Retailing, 87, S3-S16. doi: http://dx.doi.org/10.1016/j.jretai.2011.04.005

Soukhoroukova, A., Spann, M., \& Skiera, B. (2012). Sourcing, filtering, and evaluating new product ideas: An empirical exploration of the performance of idea markets. Journal of Product Innovation Management, 29(1), 100-112. doi: 10.1111/j.1540-5885.2011.00881.x

Stanko, M. A., Fisher, G. J., \& Bogers, M. (2017). Under the wide umbrella of open innovation. Journal of Product Innovation Management, 34(4), 543-558.

Stephens, D. (2013). The retail revival: Reimagining business for the new age of consumerism (Vol. 1. Aufl.; 1). CA: Wiley.

Tan, K. H., \& Zhan, Y. (2017). Improving new product development using big data: A case study of an electronics company. R\&D Management, 47(4), 570-582. doi: 10.1111/radm.12242 
Teece, D. J. (2017). Explicating dynamic capabilities the nature and micro foundations of (sustainable) enterprise performance. Strategic Management Journal, 28(13), 1319-1350.

Treem, J. W., \& Leonardi, P. M. (2012). Social media use in organizations: Exploring the affordances of visibility, editability, persistence, and association. Communication Yearbook, 36, 143-189.

Tushman, M. L., \& Katz, R. (1980). External communication and project performance: An investigation into the role of gatekeepers. Management Science, 26(11), 1071-1085. doi: 10.1287/mnsc.26.11.1071

Urquhart, C. (2013). Grounded theory for qualitative research: A practical guide. Thousand Oaks, California: Sage.

Vargo, S. L., \& Lusch, R. F. (2008). Service-dominant logic: Continuing the evolution. Journal of the Academy of Marketing Science, 36(1), 1-10.

Wang, E. T. G., Tai, J. C. F., \& Grover, V. (2013). Examining the relational benefits of improved interfirm information processing capability in buyer-supplier dyads MIS Quarterly, 37(1), 149-173.

Weiguo, F. A. N., \& Gordon, M. D. (2014). The power of social media analytics. [Article]. Communications of the ACM, 57(6), 74-81. doi: 10.1145/2602574

West, J., \& Bogers, M. (2014). Leveraging external sources of innovation: A review of research on open innovation. Journal of Product Innovation Management, 31(4), 814-831.

West, J., \& Bogers, M. (2017). Open innovation: Current status and research opportunities. Innovation: Organization \& Management, 19(1), 43-50.

West, J., Salter, A., Vanhaverbeke, W., \& Chesbrough, H. (2014). Open innovation: The next decade. Research Policy, 43(5), 805-811. doi: 10.1016/j.respol.2014.03.001

Whelan, E., Teigland, R., Donnellan, B., \& Golden, W. (2010). How internet technologies impact information flows in r\&d: Reconsidering the technological gatekeeper. $R$ and $D$ Management, 40(4), 400-413. doi: 10.1111/j.14679310.2010.00610.x

Williams, K., Chatterjee, S., \& Rossi, M. (2008). Design of emerging digital services: A taxonomy. European Journal of Information Systems, 17(5), 505-517.

Zhang, M., Sarker, S., \& Sarker, S. (2008). Unpacking the effect of it capability on the performance of export-focused smes: A report from china. Information Systems Journal, 18(4), 357-380. 


\section{Author Biographies}

Joanne Patroni is a principal consultant, Transitions and Programs, with Endpoint Consulting. She holds a Professional Doctorate in Information Technology from Queensland University of Technology. Her research focuses on social media and retail innovation. She published in IT Professional.

Frederik von Briel is a lecturer in Strategy and Entrepreneurship at UQ Business School. Most of Frederik's current research focuses on digital entrepreneurship and digital innovation. $\mathrm{He}$ received his $\mathrm{PhD}$ from City University of Hong Kong for his work on business accelerators and high-tech start-ups. Prior to joining academia, he worked as a business intelligence consultant at Hewlett-Packard and as a customer relationship management specialist at IBM.

Jan Recker is an AIS fellow, chaired professor for Information Systems and Systems Development at the University of Cologne, and adjunct professor in the QUT Business School. His research focuses on systems analysis and design, digital entrepreneurship and innovation, and environmental sustainability. 